\title{
Energy-Efficient Production of Cassava-Based Bio-Ethanol
}

\author{
Qian Kang1,2, Lise Appels1, Jan Baeyens'2, Raf Dewil1, Tianwei Tan² \\ ${ }^{1}$ Process and Environmental Technology Laboratory, Department of Chemical Engineering, \\ Sint-Katelijne-Waver, Belgium \\ ${ }^{2}$ Beijing Key Laboratory of Bioprocess, College of Life Science and Technology, Beijing University of Chemical \\ Technology, Beijing, China \\ Email: kangqian1985@gmail.com
}

Received 6 August 2014; revised 15 September 2014; accepted 2 October 2014

Copyright (C) 2014 by authors and Scientific Research Publishing Inc.

This work is licensed under the Creative Commons Attribution International License (CC BY). http://creativecommons.org/licenses/by/4.0/

(c) (i) Open Access

\section{Abstract}

Fuel ethanol is an important renewable and sustainable fuel, produced in China by fermentation of mostly corn, wheat and cassava feedstock. Fermentation produces an ethanol-lean broth (10 to 12 vol\%). Ethanol is recovered by distillation, followed by a molecular sieve drying beyond the azeotropic point. The distillation and molecular sieve operations consume most of the total energy used, with the steam consumption currently being $\sim 1.8 \mathrm{~kg} / \mathrm{kg}$ ethanol, including $0.5 \mathrm{~kg} / \mathrm{kg}$ ethanol in the final molecular sieve stage during regeneration. The objectives of the paper are fourfold: 1 ) firstly to study the distillation process of a large-scale cassava-based fuel ethanol production $[200,000$ tons per year), by field measurements and by using an Aspen Plus V8.2 simulation, with and without energy integration of condensers and reboilers, resulting in a distillation steam consumption of $\sim 1.3 \mathrm{~kg} / \mathrm{kg}$ ethanol; 2) secondly, to examine the effects of using Very High Gravity (VHG) fermentation of cassava meal mash. By using VHG fermentation, the ethanol concentration in the fermenter broth is significantly increased, to about $19 \mathrm{vol} \%(15.4 \mathrm{wt} \%)$. The steam consumption is then reduced to $\sim 0.94 \mathrm{~kg} / \mathrm{kg}$, representing a considerable saving in comparison with the current operation. Applying VHG fermentation needs minor additional investment, rapidly recovered through the energy savings and the smaller size of equipment; 3 ) thirdly, to assess the application of a hybrid operation, where pervaporation will be used to selectively and continuously remove ethanol from the fermenter broth, thus slightly increasing the fermentation yield by reducing the risk of ethanol inhibition, whilst producing an ehtanol-rich permeate (about $30 \mathrm{wt} \%$ ); and finally 4) to demonstrate that the production cost of cassava-based ethanol can substantially be reduced by applying the proposed improvements.

\section{Keywords}

Bio-Ethanol, Hybrid Process, VHG, Membranes, Energy Optimization, Simulation 


\section{Introduction}

Bio-ethanol, as a clean and renewable fuel, is gaining increasing attention. Biochemically produced by fermentation of an aqueous broth of different raw materials (corn, wheat, cassava, sugar cane...), it is purified by distillation till the water/ethanol azeotropic mix of $~ 95 \mathrm{wt} \%$ ethanol. A further removal of water to obtain $>99.5 \mathrm{wt} \%$ ethanol is commonly performed using molecular sieves.

Distillation is an energy-intensive separation process, contributing significantly to the production cost of bio-ethanol. Over the past years, a lot of research studied modified production pathways to reduce the cost of bio-ethanol, with hybrid processes and Very High Gravity (VHG) fermentation as the most important recommendations. To quantify the impact of possible improvements, and compare production cost of different alternatives, the present paper examined the 200,000 ton/year cassava-based production facility of Cofco (China) [1]-[3]. Different improvements will be assessed using literature data and own experimental results. All data will be imported into a simulation of the distillation train by using Aspen Plus V 8.2 software. The simulation and field results of the current operation will be compared. Simulations will also be performed when using VHG or pervaporation. All findings will finally be used into a tentative economic assessment.

\section{The Significant Potential of Bio-Ethanol}

With the globalization of the increasing demand for energy, its shortage is a growing worldwide problem. Bio-ethanol is considered as the alternative renewable fuel with the largest potential to replace fossil fuels. Its world production increased from 50,000 million liters in 2007 to over 100,000 million liters in 2012 [4]. The main reasons to develop bio-ethanol are diverse and linked to its possible uses 1) as a favorable carbon-neutral energy source, hence reducing $\mathrm{CO}_{2}$ emissions [5]; 2) as octane enhancer in unleaded petrol; and 3) as an oxygenated mix for a cleaner combustion of petrol, reducing tailpipe emissions and improving the ambient air quality.

In addition to the well-described fermentations of food-competing corn, wheat and sugarcane, new resources are being investigated and extensively used such as sweet sorghum and cassava, not competing with the food chain and suitable for growing in dryland conditions.

Together with bio-ethanol from carbohydrate-based feedstock such as e.g. corn, wheat, cassava (first generation), cellulose biomass (second generation) and algal biomass (third generation) are also considered. Recent references about the different generations of bio-ethanol were examined and reveal that the first generation bio-ethanol production will remain the most important production process in the immediate future [6]-[8], whilst second and third generation processes still need further development on laboratory and pilot scale to remove major drawbacks, and increase the bio-ethanol yield per input biomass weight [9]-[13].

\section{The Bio-Ethanol Production Processes}

\subsection{Schematics of Current and Possible Hybrid Operations}

The key-parts of the common bio-ethanol production, from pretreatment to dehydration and residue treatments, are illustrated in Figure 1(a), simultaneously indicating the potential use of 2 membrane techniques, being microfiltration and pervaporation (Figure 1(b)). Other membrane techniques can also be introduced (nanofiltration and reverse osmosis), but currently investigated mainly for feedstock pre-treatment and for treatment of process residues [13].

To separate the ethanol from the water phase of the broth, distillation is used until the point of the azeotropic mixture, where after residual water is removed from ethanol by molecular sieves. Distillation and molecular sieve regeneration are energy intensive processes, contributing significantly to the production cost of bio-ethanol, representing nearly $50 \%$ of the entire energy consumption [13]-[15]. The substitution of molecular sieves by membrane permeation of $\mathrm{H}_{2} \mathrm{O}$ was experimentally investigated and confirmed as a solution with high potential in a separate paper [13]. Whereas molecular sieves require $\sim 0.5 \mathrm{~kg}$ steam $/ \mathrm{kg}$ bio-ethanol during regeneration, steam is not required when using membranes, thus contributing to process energy efficiency.

\subsection{Illustration of the Cofco Cassava-Based Distillation Process}

The flow sheet of the current distillation process of a large scale cassava-based fuel ethanol production (Cofco, 


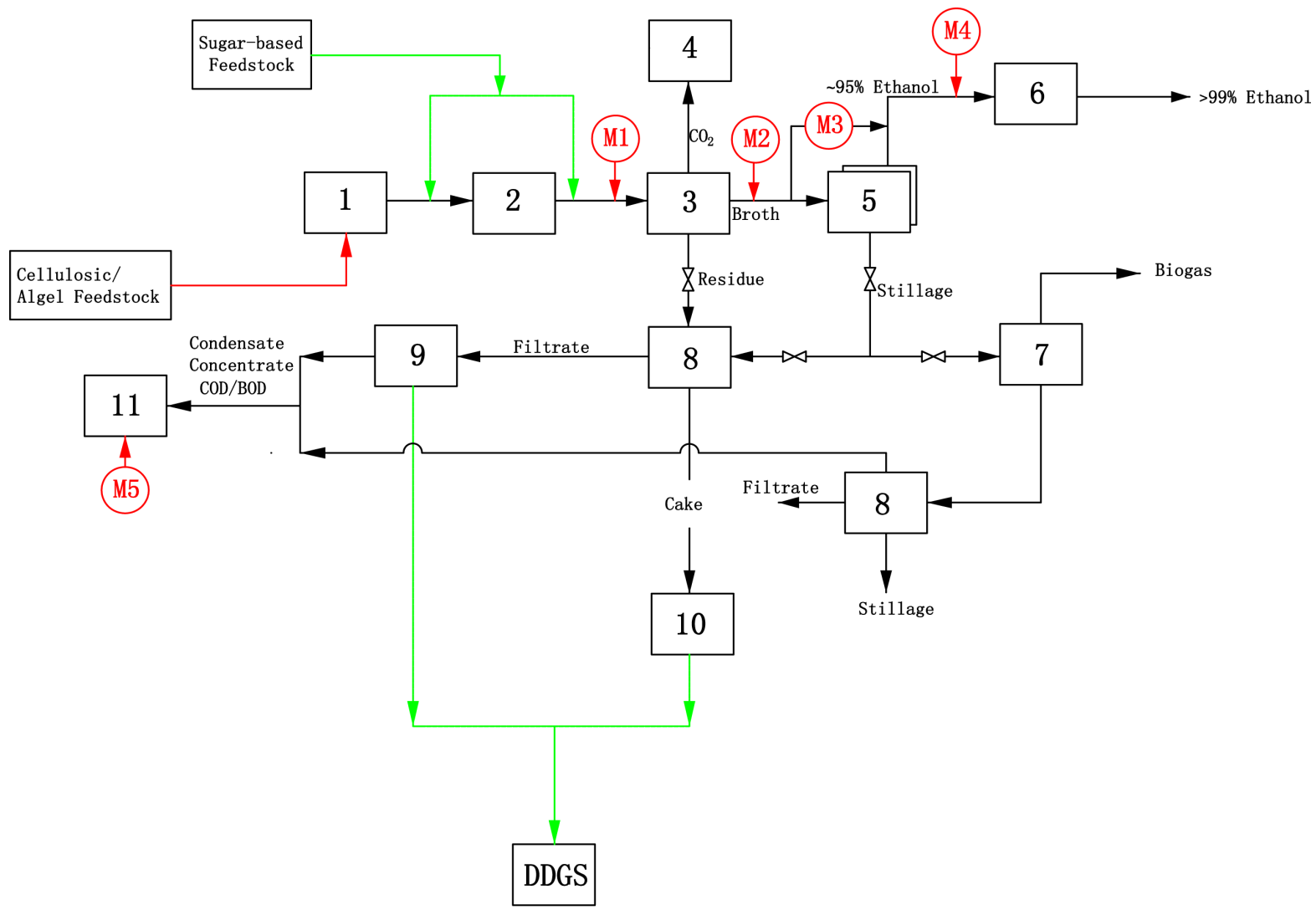

(a)

1. Pre-treatment;2. Saccharification; 3 . Fermentation; $4 . \mathrm{CO}_{2}$ Scrubbing;

5. Distillation;6. Ethanol Dehydration; 7. Anaerobic Digestion;

8. Mechanical Dewatering;9. Dryer;10. Evaporation;11. Anaerobic wastewater treatment

(b)

M1 M2. Microfiltration

M3 M4. Pervaporation

M5. Combined Membrane Processes

Figure 1. Schematics of the processes for sugar-based bio-ethanol production (a) as currently applied; (b) with potential membrane applications (DDGS: distillers dried grains with solubles; $1+2+3$ : cellulosic materials; $2+3$ : starch or carbohydrate materials).

200,000 tpa) is shown in Figure 2. It consists of a sequence of distillation columns, heat exchangers, pumps and a flash tank. The feed stream enters the crude column C1501. The distillate from C1501 is fed to column C1502. The side stream 4 is fed to the stripping section C1503-1 of the second column. C1503-2 is the rectifying section of the second column. C1503-1 has no condenser and C1503-2 has no reboiler. The bottom stream 10 enters C1502. Stream 15 is the ethanol-rich phase. The distillate from C1502 is separated via the flash tank V1504, whose gas and liquid streams are both fed to C1503. The bottom streams $(5,9,16)$ are directed to the wastewater treatment unit and are ethanol-lean ( $\leq 0.05 \mathrm{wt} \%$ ethanol). Finally the distillate from C1503-2 is further dewatered using molecular sieve absorption to the finished product of $99.7 \mathrm{wt} \%$ ethanol. Energy-integration is indicated as streams EI1 and EI2. As can be seen from Table 1, the pressure is progressively increased along the distillation train. It is hence possible to recover condenser heat to feed the reboilers of previous columns. The heat duty difference between the top of C1502 and the bottom of its neighbor C1503 is sufficient to modify the system into a combined reboiler/condenser distillation: the top high pressure condensate of condenser C1502 is used as the heat source for the reboiler of C1501. In this energy recycling scheme and accounting for a required thermal driving force in the reboilers, the remaining steam consumption would be mainly due to the bottom reboiler of C1502. 


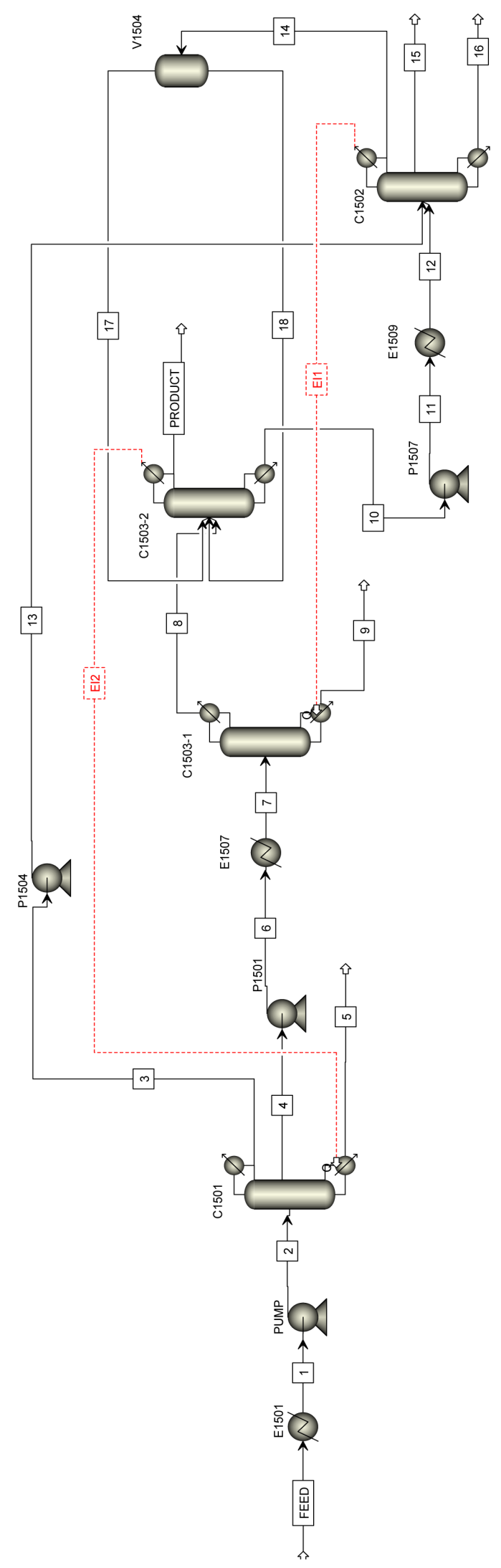

Figure 2. The distillation process of Cofco. 
The mass balance of the Cofco cassava-based process, based upon a single fermenter, is shown in Figure 3. The Cofco process uses 6 fermenters in parallel, each fermenter having a volume of $3025 \mathrm{~m}^{3}$, i.e. $\sim 3025$ ton. 865 ton of cassava flour is used per batch of 65 hrs. The production is based upon a $70 \%$ cassava starch-content and $90 \%$ starch conversion. The amount of starch converted is 549 ton. The fermentation reaction can be represented as:

$$
\mathrm{C}_{6} \mathrm{H}_{12} \mathrm{O}_{6} \rightarrow 2 \mathrm{C}_{2} \mathrm{H}_{5} \mathrm{OH}+2 \mathrm{CO}_{2}
$$

All fermenter broths are collected and dealt with in a single distillation train, working in a continuous mode. The recycle to the fermenter is applied to keep the enzyme and yeast balance at the required level.

The composition of the cassava fermentation broth contains mostly water (81.4 wt\%), ethanol (11.6 wt\%), other aliphatic alcohols ( $0.13 \mathrm{wt} \%)$, esters and acids (0.5 wt\%), glycerol (0.4 wt\%) and about $6 \mathrm{wt} \%$ of high boiling point components. The continuous feed rate to the distillation plant is $220,000 \mathrm{~kg} / \mathrm{hr}$. Referring to Figure 2 and the different key-parts of the distillation process, the number of theoretical trays and operating pressure of each column are taken from field data, and shown in Table 1.

\subsection{Comparison of Cofco Operational Data with Chemical Engineering Simulations}

The software Aspen Plus V8.2 was used. Due to the presence of the highly polar components, ethanol and glycerol,

Table 1. Operating parameters of each column.

\begin{tabular}{cccccc}
\hline Column & Number of trays & Feed tray number & Reflux ratio & Top pressure $(\mathrm{kPa})$ & Bottom pressure $(\mathrm{kPa})$ \\
\hline C1501 & 15 & 6 & 0.3 & 33.3 & 51.3 \\
C1503 & 30 & 20 & & 189.3 & 215.3 \\
C1502 & 40 & 30 & 3.1 & 600.4 & 636.7 \\
\hline
\end{tabular}

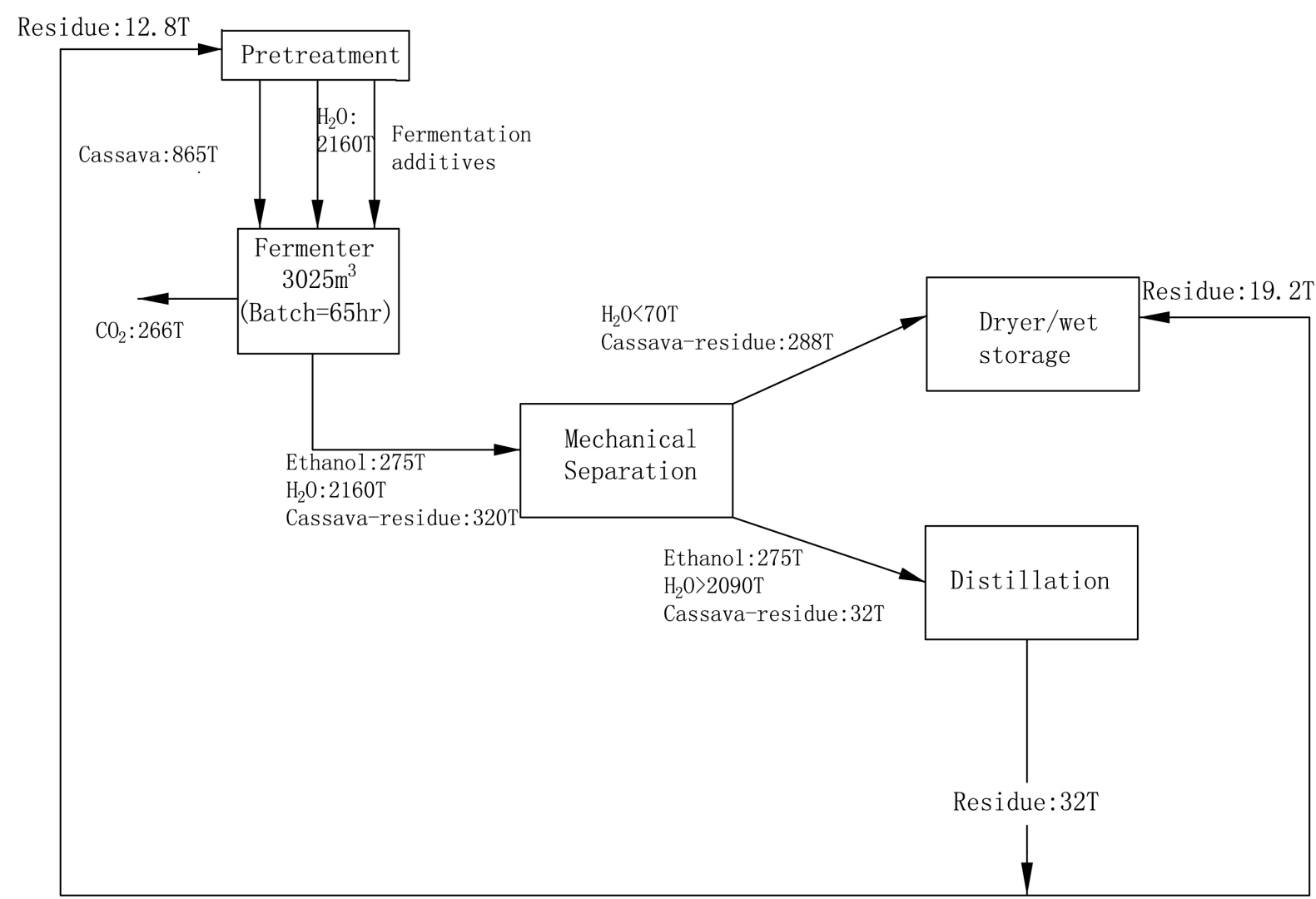

Figure 3. The mass balance of the Cofco process of cassava-based bioethanol production. 
both the non-random two liquid (NRTL) and universal quasi-chemical (UNIQUAC) thermodynamic/activity models were used to predict the activity coefficients of the components in a liquid phase [16]. Some unavailable interaction parameter coefficients were estimated using the UNIQUAC liquid-liquid equilibrium module. Simulation results towards operating temperatures in the different columns without internal energy recovery were compared with the real values of Table 1 . The comparison of Table 2 shows very fair agreement.

In the non-ideal operation mode, i.e. without internal energy re-use, the total reboiler duty amounts to:

$$
Q_{R E B}(\mathrm{~kW})=9000+18222+11604=38826 \mathrm{~kW}
$$

A conservative average enthalpy of steam is taken at $2200 \mathrm{~kJ} / \mathrm{kg}$ steam. For a total production of 25,375 kg/hr of pure ethanol, the steam requirements are:

$$
\frac{38826 \times 3600}{25375 \times 2200}=2.50 \mathrm{~kg} \text { steam } / \mathrm{kg} \text { bio -ethanol }
$$

In the integrated heat-duty operation mode, the top high pressure condensate of condenser C1502 is used as the heat source for the reboiler of C1503, and top high pressure condensate of C1503 is used as the heat source for the reboiler of C1501. In this energy recycling scheme and accounting for a required thermal driving force in the reboilers, the remaining steam consumption would be due to the bottom reboiler of C1502.

The total reboiler heat duty of the heat-integrated distillation train will be

$$
Q_{R E B}(\mathrm{~kW})=18222 \mathrm{~kW}
$$

At an average available enthalpy of $2300 \mathrm{~kJ} / \mathrm{kg}$ of steam, the energy consumption of the integrated reboilercondenser solution is

$$
\frac{18222 \times 3600}{25375 \times 2200}=1.18 \mathrm{~kg} \text { steam } / \mathrm{kg} \text { bio }- \text { ethanol }
$$

In the current Cofco operation, this reboiler-condenser integration is applied, with steam duties cited as $\sim 1.3$ $\mathrm{kg}$ steam/kg bio-ethanol.

Aspen-simulations and field data are in very fair agreement. The steam duty of $\sim 1.3 \mathrm{~kg}$ steam $/ \mathrm{kg}$ bio-ethanol can hence be considered as the energy requirement of the heat duty integrated ethanol- $\mathrm{H}_{2} \mathrm{O}$ distillation.

\section{Potential Improvements of the Basic Production Scheme}

\subsection{Very High Gravity Fermentation (VHG)}

In traditional starch fermentation, Saccharomyces cerevisiae is used as yeast, however with the drawback of inhibition at ethanol concentrations in excess of $\sim 12 \mathrm{vol} \%$. The use of specific bacteria such as Zymomonas mobilis, with higher inhibition levels, opened the way to high concentration fermentation, referred to as very high

\begin{tabular}{|c|c|c|c|c|c|c|}
\hline & \multicolumn{2}{|r|}{ C1501 } & \multicolumn{2}{|r|}{ C1503 } & \multicolumn{2}{|r|}{ C1502 } \\
\hline & Real value & Simulation value & Real value & Simulation value & Real value & Simulation value \\
\hline Top temperature $/{ }^{\circ} \mathrm{C}$ & 56.10 & 53.99 & 95.60 & 94.88 & 131.20 & 131.93 \\
\hline Bottom temperature $/{ }^{\circ} \mathrm{C}$ & 82.70 & 82.16 & 123.30 & 122.61 & 159.90 & 161.37 \\
\hline Ethanol concentration of side stream (wt\%) & 16 & 16.9 & & & & \\
\hline Final Ethanol concentration (wt\%) & & & & & $93-94$ & 93.2 \\
\hline Heat duty (kW) & \multicolumn{2}{|r|}{9000} & \multicolumn{2}{|r|}{11,604} & \multicolumn{2}{|r|}{18,222} \\
\hline Condenser & \multicolumn{2}{|r|}{5694} & \multicolumn{2}{|r|}{11,575} & \multicolumn{2}{|r|}{16,944} \\
\hline
\end{tabular}
gravity (VHG) fermentation.

The total fermentation yield can be raised by application of VHG. This technique has drawn a lot of attention

Table 2. The comparison of simulation results with real industrial production data. 
over the past few years [17]-[23]. In VHG, very high concentrations of sugars (>250 g/l) are loaded into the fermenter when compared to classical fermentation. Much higher concentrations of ethanol can be maintained in the fermenter by application of this technique, and ethanol fractions of $23.8 \mathrm{vol} \%$ (19 wt\%) have been reached [22]. Besides this advantage, a lower risk of contamination and a saving of fermenter space can be realized by using VHG fermentation. At these high ethanol concentrations, the yeasts suffer from extremely harsh conditions in the fermenter, the most important two extreme conditions being the high osmotic pressure and toxic effects of ethanol. A lot of research has been done the past few years to understand these extreme conditions and to anticipate on them. Research has been focusing on the micro-organisms themselves, added nutrients and osmoprotectants. As a result, it became clear that the fermentation rate can be raised [24] by addition of ergosterol, oleic acid or polysaccharides, whilst, higher ethanol concentrations can also be achieved when ureum, yeast-extracts or ammonia salts are added [18]. The major drawback of applying VHG fermentation is the high viscosity in the fermenter as a result of the high sugar concentrations. This high viscosity hinders the solid/liquid separation and the heat exchange during the distillation. To solve this problem Wang et al. suggest using pectine-degrading enzymes or other enzymes like xylase, cellulase and xylanase to lower the viscosity [19].

The previous simulations of the basic distillation train (Section 3.2) account for $11.6 \mathrm{wt} \%$ ethanol. If the ethanol content of the broth can be encreased, the required heat duty of the distillation can be reduced due to the reduction of $\mathrm{H}_{2} \mathrm{O}$ content of the broth.

Although VHG results up to 23.8 vol\% have been reported [22], we conservatively examined situations between 15 and 19 vol\% (12.1 and $15.2 \mathrm{wt} \%$, respectively), at a constant production of $25,375 \mathrm{~kg} / \mathrm{hr}$ of ethanol.

With VHG at $19 \mathrm{vol} \%$, the minimum reboiler duty is obtained. If again the condenser heat of C1502 recycled to the reboilers of the lower-pressure column, the required heat duty is reduced to

$$
Q_{R E B}(\mathrm{~kW})=15162 \mathrm{~kW}
$$

At an average heat supply of $2300 \mathrm{~kJ} / \mathrm{kg}$ of steam, the steam requirement is reduced to

$$
\frac{15162 \times 3600}{25375 \times 2300}=0.94 \mathrm{~kg} \text { steam } / \mathrm{kg} \text { bio }- \text { ethanol }
$$

The comparison with the energy optimization by energy-pinch alone demonstrates that a further reduction in steam requirement of $\sim 0.3 \mathrm{~kg}$ steam $/ \mathrm{kg}$ bio-ethanol is achieved.

\subsection{Energy Optimization by Integrating Partial Pervaporation}

\subsubsection{Pervaporation Experiments}

A hybrid fermentation-distillation mode by integrating pervaporation, could reduce the risk of fermenter ethanol inhibition, whilst also slightlyreducing the heat duty of the distillation by-passing the first distillation column with this ethanol- $\mathrm{H}_{2} \mathrm{O}$ stream at higher ethanol concentration, thus reducing the heat duty of the first column.

To complete a literature review as illustrated in Table 3, a confirmatory set of experiments was carried out by the authors using a pervaporation (hydrophobic) membrane of Pervatech PDMS, in a Sulzer Chemtec (Lab Test Cell Unit). Experiments were carried out with a $\sim 12$ vol\% ethanol $-\mathrm{H}_{2} \mathrm{O}$ feed, at temperatures of $37^{\circ} \mathrm{C}, 45^{\circ} \mathrm{C}$, $55^{\circ} \mathrm{C}$ and $61^{\circ} \mathrm{C}$. The ethanol concentration in the permeate was measured by calibrated Abbe-Model $2 \mathrm{~A}$ refractometer. The pervaporate vacuum was maintained constant at 1 mbar using a RVS vacuum pump (Edwards High Vacuum International). To limit mass balance errors, the permeate was fully condensed using liquid $\mathrm{N}_{2}$. The layout of the experimental rig is illustrated in Figure 4. Each experiment was repeated at least three times and results were averaged: based on the relative error of each measurement (permeate flow, membrane surface area, and ethanol concentrations), the experimental error of reported performance factors was below 5\%. Each run (at given temperature) was operated for 3 to 6 hrs. Average results are used, and detailed results are reported elsewhere [25].

Permeate flux and ethanol wt\% are presented in Figure 5(a) and Figure 5(b). It is clear that the mobility of ethanol increases at a higher temperature, thus also increasing the obtained flux without negative influence on the membrane selectivity.

A summary of design values is given in Table 4.

From the presented data it is clear that the permeate flux significantly increases as the temperature increases. From the observations of ethanol concentration in the permeate, a higher feed temperature does not result in a 
Table 3. Literature review of applying pervaporation in bio-ethanol production.

\begin{tabular}{|c|c|c|}
\hline Reference & Objectives & Main Results \\
\hline [26] & $\begin{array}{l}\text { Membrane technology for bio-ethanol } \\
\text { production }\end{array}$ & $\begin{array}{l}\text {-A highly selective and energy-saving separation process, } \\
\text { with } \sim 15 \% \text { lower costs in comparison to the batch process. }\end{array}$ \\
\hline [27] & $\begin{array}{l}\text { Significant improvement of bio-ethanol } \\
\text { recovery using a pervaporation } \\
\text { (silicone rubber-coated membrane) }\end{array}$ & $\begin{array}{l}\text {-The recovered ethanol concentration in the permeate was } 67 \mathrm{wt} \% \text {, } \\
\text { and the amount of recovered ethanol from the broth was more than } \\
10 \text { times higher than when using a noncoated membrane. }\end{array}$ \\
\hline [28] & $\begin{array}{l}\text { Pervaporative separation of bio-ethanol using a } \\
\text { polydimethylsiloxane/polyetherimide } \\
\text { composite hollow-fiber membrane }\end{array}$ & $\begin{array}{l}\text {-Possible but dependent on the feed concentration and operating } \\
\text { temperature for ethanol concentrations of } 1 \%-10 \% \text {; } \\
\text {-Relatively good pervaporation performance with a total flux of } \\
231-252 \mathrm{~g} / \mathrm{m}^{2} \mathrm{~h} \text {. }\end{array}$ \\
\hline [29] & $\begin{array}{l}\text { Enhanced bio-ethanol production by } \\
\text { pervaporation using a PDMS membrane } \\
\text { bioreactor }\end{array}$ & $\begin{array}{l}\text {-Increase of cell density, decreasing ethanol inhibition, improved } \\
\text { productivity and yield, and resumption of clean and concentrated ethanol; } \\
\text {-Ethanol productivity increased by } 26.83 \% \text { over conventional batch } \\
\text { fermentation; } \\
\text {-Ethanol concentration in permeated side was } 6 \text { to } 7 \text { times higher than } \\
\text { that of the broth. }\end{array}$ \\
\hline [30] & $\begin{array}{l}\text { Bio-ethanol recovery using the } \\
\text { pervaporation separation technique }\end{array}$ & $\begin{array}{l}\text {-Zeolite } 13 \times \text { filled CA membrane has the better pervaporation performance; } \\
\text {-Application of CA membranes in industrial scale pervaporation } \\
\text { units may be feasible for separation of ethanol/water mixtures; } \\
\text {-Bio-ethanol can be produced economically (using distillation } \\
\text { and pervaporation by hybrid systems). }\end{array}$ \\
\hline [31] & $\begin{array}{l}\text { Membrane process opportunities and } \\
\text { challenges in the bio-ethanol industry }\end{array}$ & $\begin{array}{l}\text {-As a highly selective and energy-saving unit operation, membranes } \\
\text { have a great potential in the bio-ethanol industry, both for starch-based } \\
\text { and 2nd generation technology of bio-ethanol. }\end{array}$ \\
\hline [32] & $\begin{array}{l}\text { Membrane technologies for biorefining } \\
\text { and bioenergy production }\end{array}$ & $\begin{array}{l}\text {-Pervaporation membrane bioreactors (PVMBRs) and membrane distillation } \\
\text { bioreactors (MDBRs) lead to higher ethanol productivity and minimize } \\
\text { the inhibition; } \\
\text {-Membrane hybrid processes further improve biorefining and bioenergy } \\
\text { production by decreasing energy consumption, reducing the number } \\
\text { of processing steps, and producing high quality final products. }\end{array}$ \\
\hline [33] & $\begin{array}{l}\text { Lignocellulosic ethanol through } \\
\text { polydimethylsiloxane (PDMS) membrane }\end{array}$ & $\begin{array}{l}\text {-Yeasts, solid particles, and salts can increase ethanol flux and selectivity; } \\
\text {-Integrated process can effectively eliminate product inhibition, } \\
\text { improve ethanol productivity, and enhance the glucose conversion rate. }\end{array}$ \\
\hline [34] & $\begin{array}{l}\text { Energy demand of biofuel production } \\
\text { applying distillation and/or pervaporation }\end{array}$ & $\begin{array}{l}\text {-Multi-stage pervaporation is needed to reach the fuel-grade quality } \\
\text { of the bio-ethanol. }\end{array}$ \\
\hline
\end{tabular}

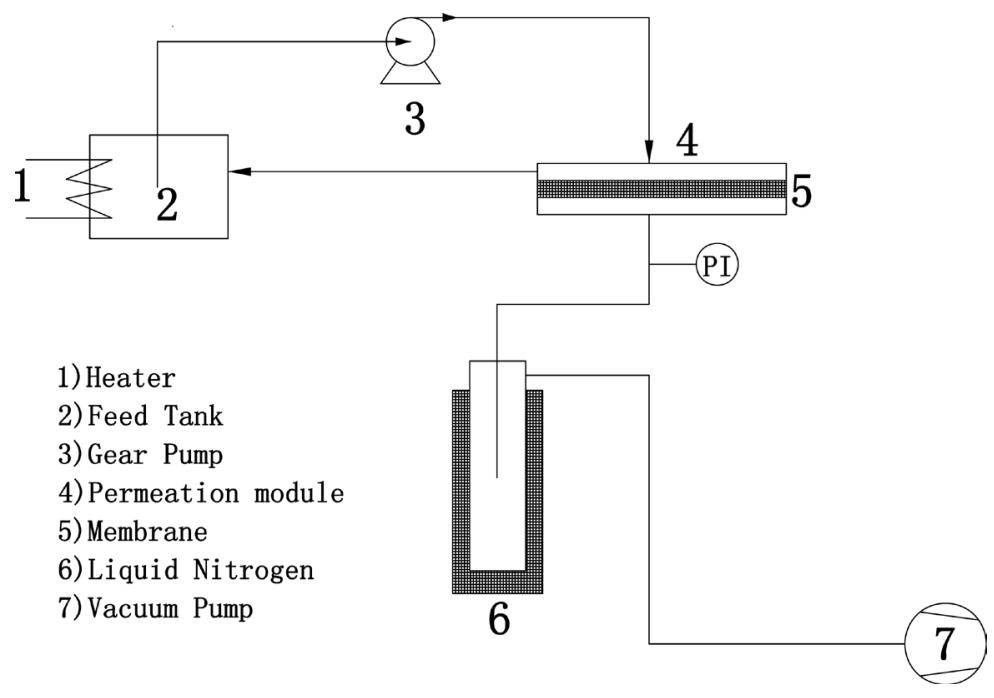

Figure 4. The experimental pervaporation rig. 


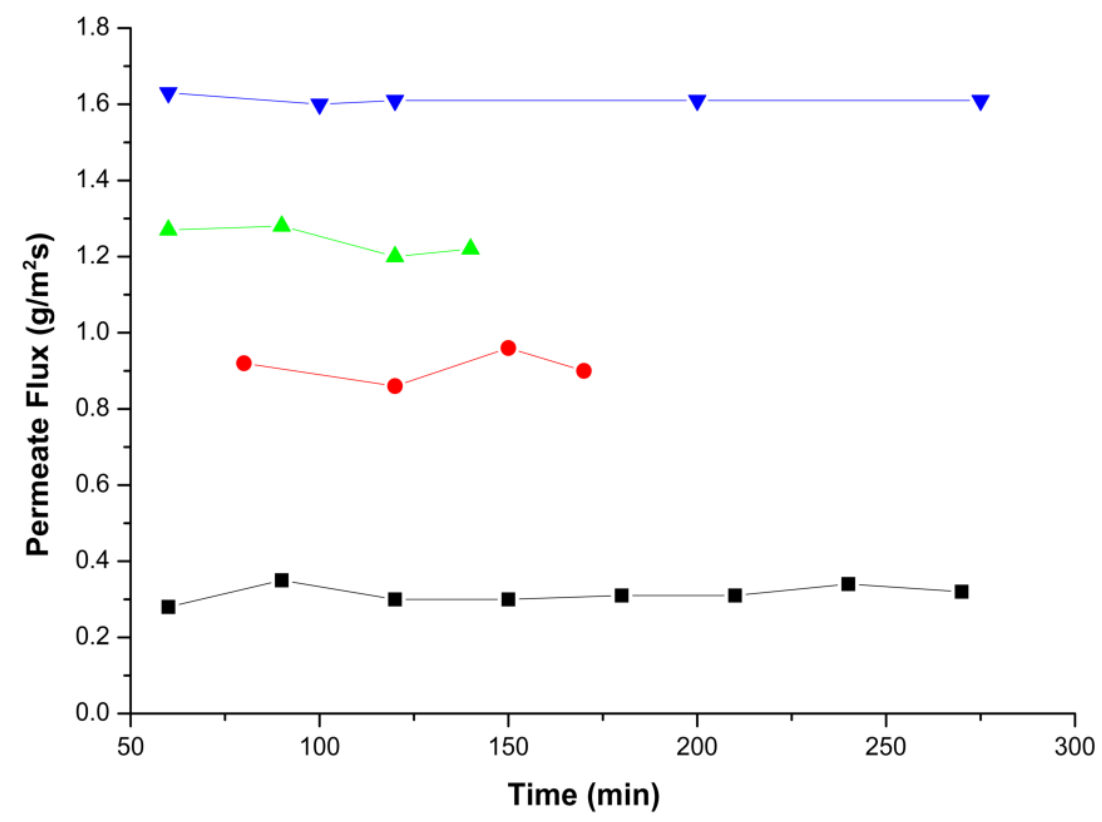

(a)

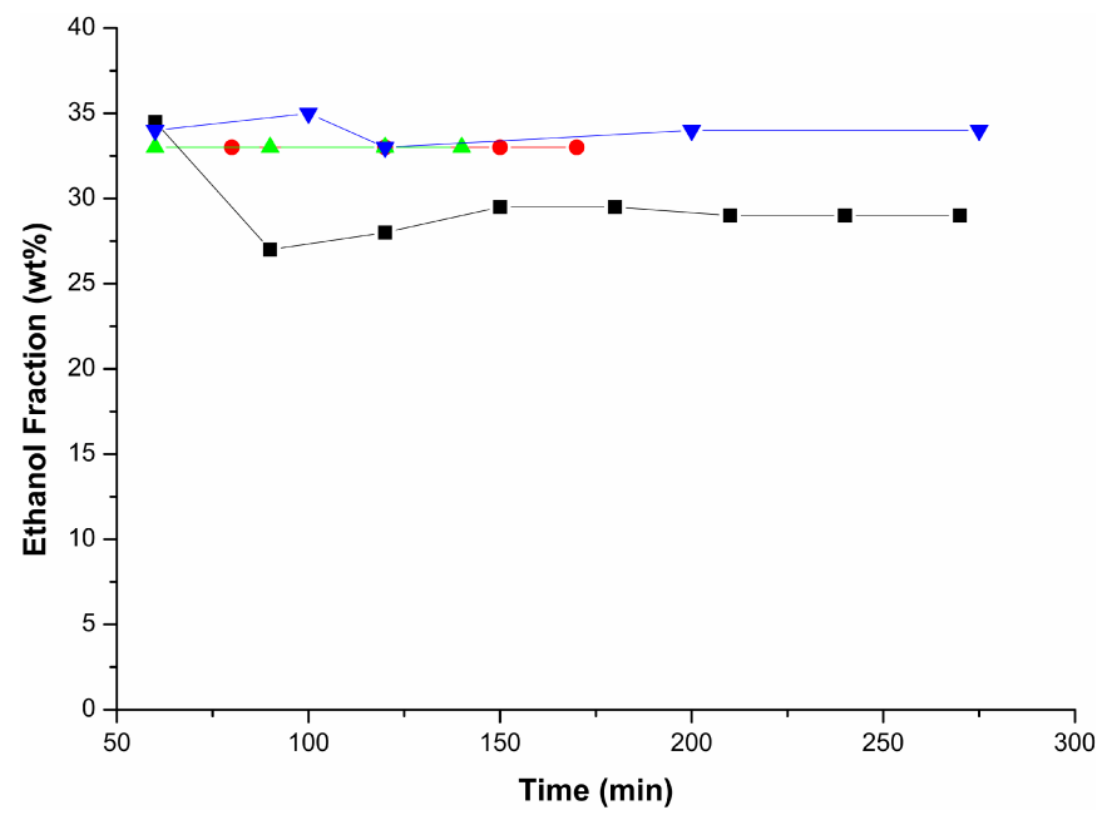

(b)

Figure 5. Permeate characteristics as function of operating time $\left(\boldsymbol{\varpi}: 37^{\circ} \mathrm{C} ; \bullet: 45^{\circ} \mathrm{C} ; \boldsymbol{\Delta}\right.$ : $\left.50^{\circ} \mathrm{C} ; \boldsymbol{\nabla}: 61^{\circ} \mathrm{C}\right)$.

Table 4. Permeate flux and ethanol concentration at different temperature.

\begin{tabular}{ccc}
\hline Temperature $\left({ }^{\circ} \mathrm{C}\right)$ & Ethanol in Permeate $(\mathrm{wt} \%)$ & Permeate Flux $\left(\mathrm{g} / \mathrm{m}^{2} \mathrm{~s}\right)$ \\
\hline 37 & 28.7 & 0.32 \\
45 & 33 & 0.91 \\
55 & 33 & 1.24 \\
61 & 34 & 1.61 \\
\hline
\end{tabular}


higher ethanol membrane selectivity. Since ethanol molecules have a larger size than water, the assumption can be made that diffusion effects are dominant over sorption effects, and are thus expected to be the determining parameter in the transport mechanism description through the PDMS-based membrane. It is expected that the minor increase of the selectivity at higher temperature is explained by a dependent decrease of the hydrogen bonding between water and alcohol molecules. When this is the case less water is stimulated to permeate through the membrane. Hence, not only swelling seems to play an important role during ethanol/water pervaporation but also the coupling effects between molecules, which tend to be lower at higher temperatures.

\subsubsection{Extrapolation of the Experimental Results to the Target Unit (200,000 t/yr Ethanol)}

To reduce the ethanol concentration in the fermenter below the inhibition threshold limit, it is proposed to continuously remove $25 \%$ of the total fermenter flow rates through the membrane. Since the fermenter discharges $220,000 \mathrm{~kg} / \mathrm{hr}$ of ethanol- $\mathrm{H}_{2} \mathrm{O}$ mixture at $11.6 \mathrm{wt} \%$ ethanol, the feed rate to the pervaporation unit will be 55,000 $\mathrm{kg} / \mathrm{hr}$. Operating parameters for the large-scale application are given in Table 5.

Although it is expected that the continuous removal of ethanol will slightly increase the yield of the fermenter due to suppressing ethanol inhibition, this was not accounted for in the calculations.

With the given experimental results and operation data of Table 5 , the following steady-state mass balance prevails.

$$
\begin{aligned}
& F_{\text {FEED }}=F_{\text {PERMEATE }}+F_{\text {ReteNTATE }}+F_{\text {COLUMN }} \\
& F_{\text {FEed }} \times X_{\text {FeEd }}=F_{\text {Permeate }} X_{\text {Permeate }}+F_{\text {Retentate }} X_{\text {Retentate }}+F_{\text {Column }} X_{\text {Column }} \\
& F_{\text {PERMEATE }}=7920 \mathrm{~kg} / \mathrm{hr} \\
& F_{\text {RETENTATE }}=47080 \mathrm{~kg} / \mathrm{hr} \\
& F_{\text {COLUMN }}=165000 \mathrm{~kg} / \mathrm{hr}
\end{aligned}
$$

Both $F_{\text {RETENTATE }}$ and $F_{\text {COLOmn }}$ are fed to C1501. With a $33 \mathrm{wt} \%$ ethanol content in the permeate, $2614 \mathrm{~kg} / \mathrm{hr}$ of ethanol is continuously removed from the fermenter, reducing the effective concentration to $<10.8 \mathrm{wt} \%$.

It is proposed to feed the pervaporation permeate directly to C1503-1 in view of its concentration of ethanol ( $\sim 33 \mathrm{wt} \%$, i.e. $\sim 41 \mathrm{vol} \%)$.

The required membrane surface area is $7920 / 5.8=1366 \mathrm{~m}^{2}$. Although this surface area is considerable, it can be reduced by:

1) Operating the pervaporation at as close a temperature as possible to the azeotropic point $\left(\sim 78^{\circ} \mathrm{C}\right)$, hence e.g. $75^{\circ} \mathrm{C}$. Extrapolating the T-dependent flux to $75^{\circ} \mathrm{C}$, yields values of $\sim 2.4 \mathrm{~g} / \mathrm{m}^{2} \mathrm{~s}$ or $8.7 \mathrm{~kg} / \mathrm{m}^{2} \mathrm{~h}$, leading to a reduction in membrane surface by $50 \%$.

2) The selection of a different membrane material, as suggested in the literature, where fluxes up to $10 \mathrm{~kg} / \mathrm{m}^{2} \mathrm{~h}$ at comparable or higher selectivities were indicated.

3) It is not considered to operate the pervaporation membranes at higher ethanol concentrations, hence e.g. in

\begin{tabular}{|c|c|}
\hline Parameter & Value \\
\hline$F_{\text {FEED }}$ & $220,000 \mathrm{~kg} / \mathrm{hr}$ \\
\hline$X_{\mathrm{FEED}}$ & $11.6 \mathrm{wt} \%$ \\
\hline$X_{\text {PERMEATE }}$ & $33 \mathrm{wt} \%$ \\
\hline$X_{\text {RETEntate }}$ & $8 \mathrm{wt} \%$ \\
\hline$Q_{\text {PERMEATE }}\left(61^{\circ} \mathrm{C}\right)$ (Table 4$)$ & $5.8 \mathrm{~kg} / \mathrm{m}^{2} \mathrm{~h}$ \\
\hline
\end{tabular}
association with VHG, since it was demonstrated by Chovau [35] that the selectivity of all examined membranes is strongly dependent on the alcohol content in the feed: a higher concentration of selective compound (ethanol) in the feed led to a decrease in membrane selectivity. Similar observations were found by Chen et al. [36], who investigated the performance of unsupported PDMS-membranes in the separation of ethanol/water mixtures 
ranging between 4 and $91 \mathrm{wt} \%$ of ethanol in the feed, and explained the decrease by an extensive swelling of the PDMS rubber at higher feed ethanol concentrations. According to Jia et al. [37], incorporation of silicalite fillers in the polymeric network results in a reduction of membrane swelling and moreover improves the mechanical strength of the active layer.

\subsubsection{Effect on the Overall Steam Requirements of the Distillation}

Whilst using the same distillation column outlays (Table 1), the mass and heat balances around the complete unit, as illustrated in Table 2 before for a total $220,000 \mathrm{~kg} / \mathrm{hr}$ of broth fed at $11.6 \mathrm{wt} \%$, are now slightly modified with ( $\left.F_{\text {COLUMN }}+F_{\text {RETENTATE }}\right)$ being fed to C1501 at $10.8 \mathrm{wt} \%$ ethanol.

With this operating mode, and internal energy reuse, the Aspen simulations revealed a required steam duty of the complete distillation train as given in Table 6.

Since condenser heat of C1502 is reused in reboiler C1501, and C1503-1, and condenser heat of C1503-2 is also used in C1501, the remaining net heat duty to be supplied from the steam network is reduced to 18,222 $\mathrm{kW}$, or:

$$
\frac{18222 \times 3600}{25375 \times 2300}=1.13 \mathrm{~kg} \text { steam } / \mathrm{kg} \text { bio -ethanol }
$$

\subsection{Effect on the Overall Steam Requirements of the Distillation}

Combining the previous simulation results, the following overall evolution of steam consumption in the distillation emerges (Table 7).

As a conclusion, the steam use per kg of bio-ethanol is reduced from 1.18 to $1.17,0.94$ and $1.13 \mathrm{~kg}$ steam $/ \mathrm{kg}$ bio-ethanol for options VHG (15\%), VHG (19\%) and pervaporation, respectively.

\section{Tentative Economic Assessment}

The full production cost of bio-ethanol at Cofco in 2013 is reported at $820 € /$ ton bio-ethanol. Based upon the predictions of the previous sections, a tentative cost calculation per ton bio-ethanol can be made, for a plant depreciation of 25 years, and other costs calculated on the basis of common ratios or literature data [38]. The efficiency of the steam boiler is estimated at $85 \%$. The following Table 8 summarizes the calculations for the basis Cofco-like flowsheet.

Since the estimated production cost for cassava-based bio-ethanol (815 €/ton) is comparable with the Cofcocited $820 € /$ ton, the proposed calculation procedure appears fair and acceptable.

Through a similar approach, and based upon estimated investment costs of the membrane module, the impact of hybrid pervaporation and/or VHG can be calculated. The life span of the membrane modules is estimated at 10 years, with a replacement of the membranes every 4 years. The total steam duty of the distillation section is then reduced to $\sim 0.9 \mathrm{~kg} / \mathrm{kg}$ bio-ethanol. The steam duty of the molecular sieve operation still needs to be added.

The impact of the VHG operation of the fermenter is given in Table 9 .

Table 6. Simulation results of the hybrid operation mode.

\begin{tabular}{ccccc}
\hline & C1501 & C1502 & C1503-1 & C1503-2 \\
\hline Reboiler duty (kW) & 8676 & 18,222 & 15,390 & \\
Condensor duty (kW) & 5410 & 16,944 & & 15,081 \\
\hline
\end{tabular}

Table 7. Summary results of the simulation of the Cofco distillation process.

\begin{tabular}{cc} 
Simulation & Steam consumption (kg steam/kg ethanol) \\
\hline Basic (no heat integration) & 2.50 \\
Integrating reboilers and condensers & 1.18 \\
VHG (15\%) & 1.17 \\
VHG (19\%) & 0.94 \\
Pervaporation & 1.13 \\
\hline
\end{tabular}


Table 8. Cost calculations for the current Cofco operation.

\begin{tabular}{|c|c|c|}
\hline Parameter & Value & Unit \\
\hline Annual bio-ethanol production & 200,000 & Ton bio-ethanol/year \\
\hline Depreciation & 7 & $€ /$ ton bio-ethanol \\
\hline Plant overheads & 80 & €/ton bio-ethanol \\
\hline Insurance & 1.8 & $€ /$ ton bio-ethanol \\
\hline Spare parts and maintenance & 22.4 & $€ /$ ton bio-ethanol \\
\hline Labour & 11 & $€ /$ ton bio-ethanol \\
\hline Electricity & 105 & kWh/ton bio-ethanol \\
\hline Cost of electricity & 6.1 & €/ton bio-ethanol \\
\hline Steam duty (incl. molecular sieves) ${ }^{*}$ & 1.8 & $\mathrm{~kg} / \mathrm{kg}$ bio-ethanol \\
\hline Cost of heavy fuel oil & 102 & $€ /$ ton bio-ethanol \\
\hline Demi-water for boiler & 23 & $€ /$ ton bio-ethanol \\
\hline Cassava & 6.6 & Ton/ton bio-ethanol [39] \\
\hline Purchase of cassava & 38.6 & $€ /$ ton cassava [40] \\
\hline Cost of cassava & 254.8 & $€ /$ ton bio-ethanol \\
\hline Pre-treatment of cassava & 132 & $€ /$ ton bio-ethanol \\
\hline Treatment of residues (solid/wastewater) & 144 & $€ /$ ton bio-ethanol \\
\hline \multicolumn{3}{|c|}{ TOTAL } \\
\hline Cassava & 815 & $€ /$ ton bio-ethanol \\
\hline
\end{tabular}

\footnotetext{
${ }^{*}$ The steam requirement for regenerating the molecular sieves amounts to $0.5 \mathrm{~kg} / \mathrm{kg}$ bio-ethanol.
}

Table 9. Economic impact of integrating pervaporation (hybrid process) or VHG.

\begin{tabular}{|c|c|c|}
\hline Parameter & Value & Unit \\
\hline Annual bio-ethanol production & 200,000 & Ton bio-ethanol/year \\
\hline Additional depreciation & 0.8 & €/ton bio-ethanol \\
\hline New steam duty (incl. molecular sieve) & 1.4 & $\mathrm{~kg} / \mathrm{kg}$ bio-ethanol \\
\hline Cost of heavy fuel oil & 79 & $€ /$ ton bio-ethanol \\
\hline Reduced Demi-water for boiler & 11 & $€ /$ ton bio-ethanol \\
\hline Reduced residue treatment $(-15 \%)$ & 123 & $€ /$ ton bio-ethanol \\
\hline \multicolumn{3}{|c|}{ Comparison } \\
\hline Difference with equivalent items of Table 8 & -56 & €/ton bio-ethanol \\
\hline Corrected cost for cassava-based production & $\sim 759$ & €/ton bio-ethanol \\
\hline
\end{tabular}

The production cost by applying a hybrid operation and/or VHG, can reduce the total production cost by 56 $€ /$ ton bio-ethanol, i.e. about 7\%. For an annual production of 200,000 ton of bio-ethanol, savings of $11,000,000$ $€$ are achieved.

Further research on both principles, preferably on pilot scale, appears economically and technically justified.

It should moreover be considered that molecular sieves can also be replaced by a hydrophilic membrane, hence operating without steam requirement. The steam duty is then further reduced by $0.5 \mathrm{~kg}$ steam $/ \mathrm{kg}$ bio- 
ethanol, representing a further saving on heavy fuel oil of minimum $28 € /$ ton bio-ethanol as [13].

\section{Conclusions}

To reduce the distillation-related energy-impact on the production costs of bio-ethanol, the paper investigated the effect of implementing different possible improvements into the traditional fermentation-distillation sequence. The comparison was made by Aspen Plus (V 8.2) simulation, and the current operation of the 200,000 ton/year bio-ethanol plant of Cofco (China) was used as basis. Literature and experimental data were gathered to define the results of possible VHG and pervaporation improvements.

A first improvement, implementing the energy-pinch approach enables to integrate recycle condenser and reboiler heat duties. This reduced the steam duty from 2.50 (basic operation, without energy recycle) to $1.18 \mathrm{~kg}$ steam/kg bio-ethanol.

Further improvements are still possible, with VHG (at 19\%) reducing the steam consumption to $<1 \mathrm{~kg}$ steam $/ \mathrm{kg}$ bio-ethanol, whilst operation in a hybrid mode (pervaporation of $25 \%$ of the fermenter broth) achieves $~ 20 \%$ of savings, but significantly reduces the risk of inhibition in the fermenter.

Finally, a preliminary economic analysis reveals that the factory-gate price of cassava-based bio-ethanol could be reduced from $\sim 820 € /$ ton to $\sim 760 € /$ ton.

\section{Acknowledgements}

This work was supported by the National Basic Research Program of China (973 program) (2013CB733600, 2012CB725200, 2011CB710800), the National Nature Science Foundation of China (21076017), National High-Tech R\&D Program of China (863 Program) (2012AA021404, 2012AA021402, 2014AA021903), Key Projects in the National Science \& Technology Pillar Program during the 12th Five-Year Plan Period (2011BAD22B04).

\section{References}

[1] Zhang, H.L., Baeyens, J. and Tan, T.W. (2012) Mixing Phenomena in a Large-Scale Fermenter of Starch to BioEthanol. Energy, 48, 380-391. http://dx.doi.org/10.1016/j.energy.2012.05.015

[2] Zhang, H.L., Baeyens, J. and Tan, T.W. (2012) The Bubble-Induced Mixing in Starch-To-Ethanol Fermenters. Chemical Engineering Research and Design, 90, 2122-2128. http://dx.doi.org/10.1016/j.cherd.2012.05.003

[3] Liu, S.H. and Liu, X.F. (2010) Technological Development of Non-Grain Based Fuel Ethanol Production. Liquor Making, 37, 9-11.

[4] Renewable Fuels Association (2013) World Fuel Ethanol Production. http://ethanolrfa.org/pages/World-Fuel-Ethanol-Production

[5] Bradshaw, M.J. (2010) Global Energy Dilemmas: A Geographical Perspective. The Geographical Journal, 176, 275290. http://dx.doi.org/10.1111/j.1475-4959.2010.00375.x

[6] Sanchez, O.J. and Cardona, C.A. (2008) Trends in Biotechnological Production of Fuel Ethanol from Different Feedstocks. Bioresource Technology, 99, 5270-5295. http://dx.doi.org/10.1016/j.biortech.2007.11.013

[7] Marina, O.S.D., Tassia, L.J., Carlos, E.V.R., Rubens, M.F. and Antonio, B. (2013) Evaluation of Process Configurations for Second Generation Integrated with First Generation Bioethanol Production from Sugarcane. Fuel Processing Technology, 109, 84-89. http://dx.doi.org/10.1016/j.fuproc.2012.09.041

[8] Balat, M. (2011) Production of Bioethanol from Lignocellulosic Materials via the Biochemical Pathway: A Review. Energy Conversion and Management, 52, 858-875. http://dx.doi.org/10.1016/i.enconman.2010.08.013

[9] Yu, S.R. and Tao, J. (2009) Economic, Energy and Environmental Evaluations of Biomass-Based Fuel Ethanol Projects Based on Life Cycle Assessment and Simulation. Applied Energy, 86, 178-188. http://dx.doi.org/10.1016/j.apenergy.2009.04.016

[10] Cheng, J.J. and Timilsina, G.R. (2011) Status and Barriers of Advanced Biofuel Technologies: A Review. Renewable Energy, 36, 3541-3549. http://dx.doi.org/10.1016/j.renene.2011.04.031

[11] Zhang, J., Osmani, A., Awudu, I. and Gonela, V. (2013) An Integrated Optimization Model for Switchgrass-Based Bioethanol Supply Chain. Applied Energy, 102, 1205-1217. http://dx.doi.org/10.1016/j.apenergy.2012.06.054

[12] Ojeda, K., Sánchez, E. and Kafarov, V. (2011) Sustainable Ethanol Production from Lignocellulosic Biomass-Application of Exergy Analysis. Energy, 36, 2119-2128. http://dx.doi.org/10.1016/j.energy.2010.08.017

[13] Kang, Q., Huybrechts, J., Van der Bruggen, B., Baeyens, J., Tan, T.W. and Dewil, R. (2014) Hydrophilic Membranes 
to Replace Molecular Sieves in Dewatering the Bio-Ethanol/Water Azeotropic Mixture. Separation and Purification Technology (in Press). http://dx.doi.org/10.1016/j.seppur.2014.09.009

[14] Hao, H.Y., Deng, L.K. and Du, J.B. (2009) Discussion on Energy Comprehensive Utilization Pattern in Cassava Fuel Ethanol Production Process. Cereal and Food Industry, 16, 30-33.

[15] Lucia, A. and McCallum, B.R. (2010) Energy Targeting and Minimum Energy Distillation Column Sequences. Computers \& Chemical Engineering, 34, 931-942. http://dx.doi.org/10.1016/j.compchemeng.2009.10.006

[16] Luyben, W.L. (2005) Control of a Multiunit Heterogeneous Azeotropic Distillation Process. AIChE Journal, 52, 623637. http://dx.doi.org/10.1002/aic.10650

[17] Zhang, L., Chen, Q., Jin, Y.L., Xue, H.L., Guan, J.F., Wang, Z.Y., et al. (2010) Energy-Saving Direct Ethanol Production from Viscosity Reduction Mash of Sweet Potato at Very High Gravity (VHG). Fuel Processing Technology, 91, 1845-1850. http://dx.doi.org/10.1016/j.fuproc.2010.08.009

[18] Srichuwong, S., Fujiwara, M., Wang, X.H., Seyama, T., Shiroma, R., Arakane, M., et al. (2009) Simultaneous Saccharification and Fermentation (SSF) of Very High Gravity (VHG) Potato Mash for the Production of Ethanol. Biomass and Bioenergy, 33, 890-898. http://dx.doi.org/10.1016/j.biombioe.2009.01.012

[19] Wang, F.Q., Gao, C.J., Yang, C.Y. and Xu, P. (2007) Optimization of an Ethanol Production Medium in Very High Gravity Fermentation. Biotechnology Letters, 29, 233-236. http://dx.doi.org/10.1007/s10529-006-9220-6

[20] Behera, S., Mohanty, R.C. and Ray, R.C. (2010) Comparative Study of Bio-Ethanol Production from Mahula (Madhuca latifolia L.) Flowers by Saccharomyces cerevisiae and Zymomonas mobilis. Applied Energy, 87, 2352-2355. http://dx.doi.org/10.1016/j.apenergy.2009.11.018

[21] Puligundla, P., Smogrovicova, D., Obulam, V.S. and Ko, S. (2011) Very High Gravity (VHG) Ethanolic Brewing and Fermentation: A Research Update. Journal of Industrial Microbiology \& Biotechnology, 38, 1133-1144. http://dx.doi.org/10.1007/s10295-011-0999-3

[22] Thomas, K.C., Hynes, S.H., Jones, A.M. and Ingledew, W.M. (1993) Production of Fuel Alcohol from Wheat by VHG Technology: Effect of Sugar Concentration and Fermentation Temperature. Applied Biochemistry and Biotechnology, 43, 211-226. http://dx.doi.org/10.1007/BF02916454

[23] Hu, C.K., Qin, Q. and Gao, P.P. (2011) Medium Optimization for Improved Ethanol Production in Very High Gravity Fermentation. Chinese Journal of Chemical Engineering, 19, 1017-1022. http://dx.doi.org/10.1016/S1004-9541(11)60085-2

[24] Pham, T.N.L., Doan, N.H.D. and Le, V.V.M. (2010) Using Fed-Batch Fermentation in Very High Gravity Brewing: Effects of Tween 80 and Ergosterol Supplementation on Fermentation Performance of Immobilized Yeast in Calcium Alginate Gel. International Food Research Journal, 17, 995-1002.

[25] Kang, Q. (2014) Improvement of Cassava-Based Bio-Ethanol Production. Ph.D. Dissertation (under Review), Beijing University of Chemical Technology, Beijing.

[26] Wei, P., Cheng, L.H., Zhang, L., Xu, X.H., Chen, H.L. and Gao, C.J. (2014) A Review of Membrane Technology for Bioethanol Production. Renewable and Sustainable Energy Reviews, 30, 388-400. http://dx.doi.org/10.1016/j.rser.2013.10.017

[27] Ikegami, T., Kitamoto, D., Negishi, H., Haraya, K., Matsuda, H., Nitanai, Y., et al. (2003) Drastic Improvement of Bioethanol Recovery Using a Pervaporation Separation Technique Employing a Silicone Rubber-Coated Silicalite Membrane. Journal of Chemical Technology and Biotechnology, 78, 1006-1010. http://dx.doi.org/10.1002/jctb.897

[28] Lee, H.J., Cho, E.J., Kim, Y.G., Choi, I.S. and Bae, H.J. (2012) Pervaporative Separation of Bioethanol Using a Polydimethylsiloxane/Polyetherimide Composite Hollow-Fiber Membrane. Bioresource Technology, 109, 110-115. http://dx.doi.org/10.1016/j.biortech.2012.01.060

[29] Esfahanian, M., Ghorbanfarahi, A.H., Ghoreyshi, A.A., Najafpour, G., Younesi, H. and Ahmad, A.L. (2013) Enhanced Bioethanol Production in Batch Fermentation by Pervaporation Using a PDMS Membrane Bioreactor. International Journal of Engineering-Transactions B: Applications, 25, 249-258.

[30] Hilmioglu, N.D. (2009) Bioethanol Recovery Using the Pervaporation Separation Technique. Management of Environmental Quality, 20, 165-174. http://dx.doi.org/10.1108/14777830910939471

[31] Lipnizki, F. (2010) Membrane Process Opportunities and Challenges in the Bioethanol Industry. Desalination, 250, 1067-1069. http://dx.doi.org/10.1016/j.desal.2009.09.109

[32] He, Y., Bagley, D.M., Leung, K.T., Liss, S.N. and Liao, B.Q. (2012) Recent Advances in Membrane Technologies for Biorefining and Bioenergy Production. Biotechnology Advances, 30, 817-858. http://dx.doi.org/10.1016/j.biotechadv.2012.01.015

[33] Chen, J.W., Zhang, H.M., Wei, P., Zhang, L. and Huang, H. (2014) Pervaporation Behavior and Integrated Process for Concentrating Lignocellulosic Ethanol through Polydimethylsiloxane (PDMS) Membrane. Bioprocess and Biosystems 
Engineering, 37, 183-191. http://dx.doi.org/10.1007/s00449-013-0984-5

[34] Nagy, E. and Boldyryev, S. (2013) Energy Demand of Biofuel Production Applying Distillation and/or Pervaporation. Chemical Engineering Transactions, 35, 265-270.

[35] Chovau, S., Gaykawad, S., Straathof, A.J.J. and Van der Bruggen, B. (2011) Influence of Fermentation By-Products on the Purification of Ethanol from Water Using Pervaporation. Bioresource Technology, 102, 1669-1674. http://dx.doi.org/10.1016/j.biortech.2010.09.092

[36] Chen, X., Ping, Z.H. and Long, Y.C. (1998) Separation Properties of Alcohol-Water Mixture through Silicalite1-Filled Silicone Rubber Membranes by Pervaporation. Journal of Applied Polymer Science, 67, 629-636. http://dx.doi.org/10.1002/(SICI)1097-4628(19980124)67:4<629::AID-APP5>3.0.CO;2-4

[37] Jia, M.D., Peinemann, K.V. and Behling, R.D. (1992) Preparation and Characterization of Thin-Film Zeolite-PDMS Composite Membranes. Journal of Membrane Science, 73, 119-128. http://dx.doi.org/10.1016/0376-7388(92)80122-Z

[38] Green, D.W. and Perry, R.H. (2008) Perry’s Chemical Engineering Handbook. 8th Edition, McGraw-Hill, New York, Chapter 9: Process Economics.

[39] Jansson, C., Westerbergh, A., Zhang, J.M., Hu, X.W. and Sun, C.X. (2009) Cassava, a Potential Biofuel Crop in the People’s Republic of China. Applied Energy, 86, S95-S99. http://dx.doi.org/10.1016/j.apenergy.2009.05.011

[40] Poramacom, N. (2013) Cassava Production, Prices and Related Policy in Thailand. American International Journal of Contemporary Research, 3, 43-50. 
Scientific Research Publishing (SCIRP) is one of the largest Open Access journal publishers. It is currently publishing more than 200 open access, online, peer-reviewed journals covering a wide range of academic disciplines. SCIRP serves the worldwide academic communities and contributes to the progress and application of science with its publication.

Other selected journals from SCIRP are listed as below. Submit your manuscript to us via either submit@scirp.org or Online Submission Portal.
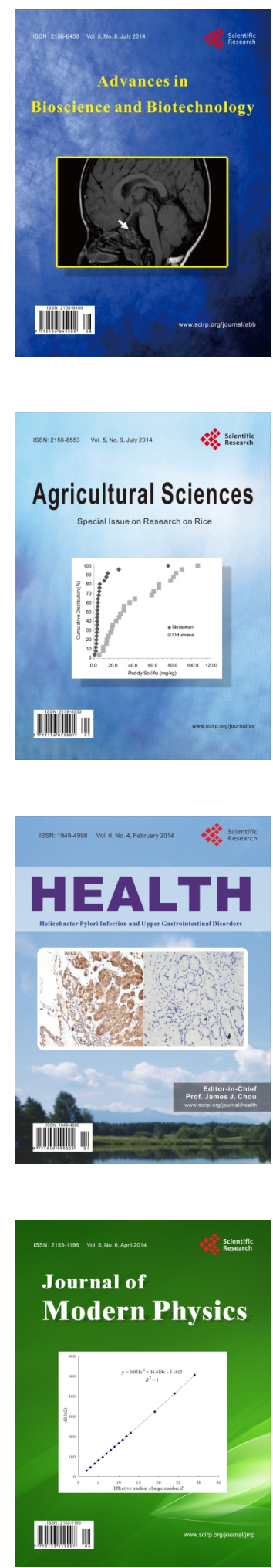
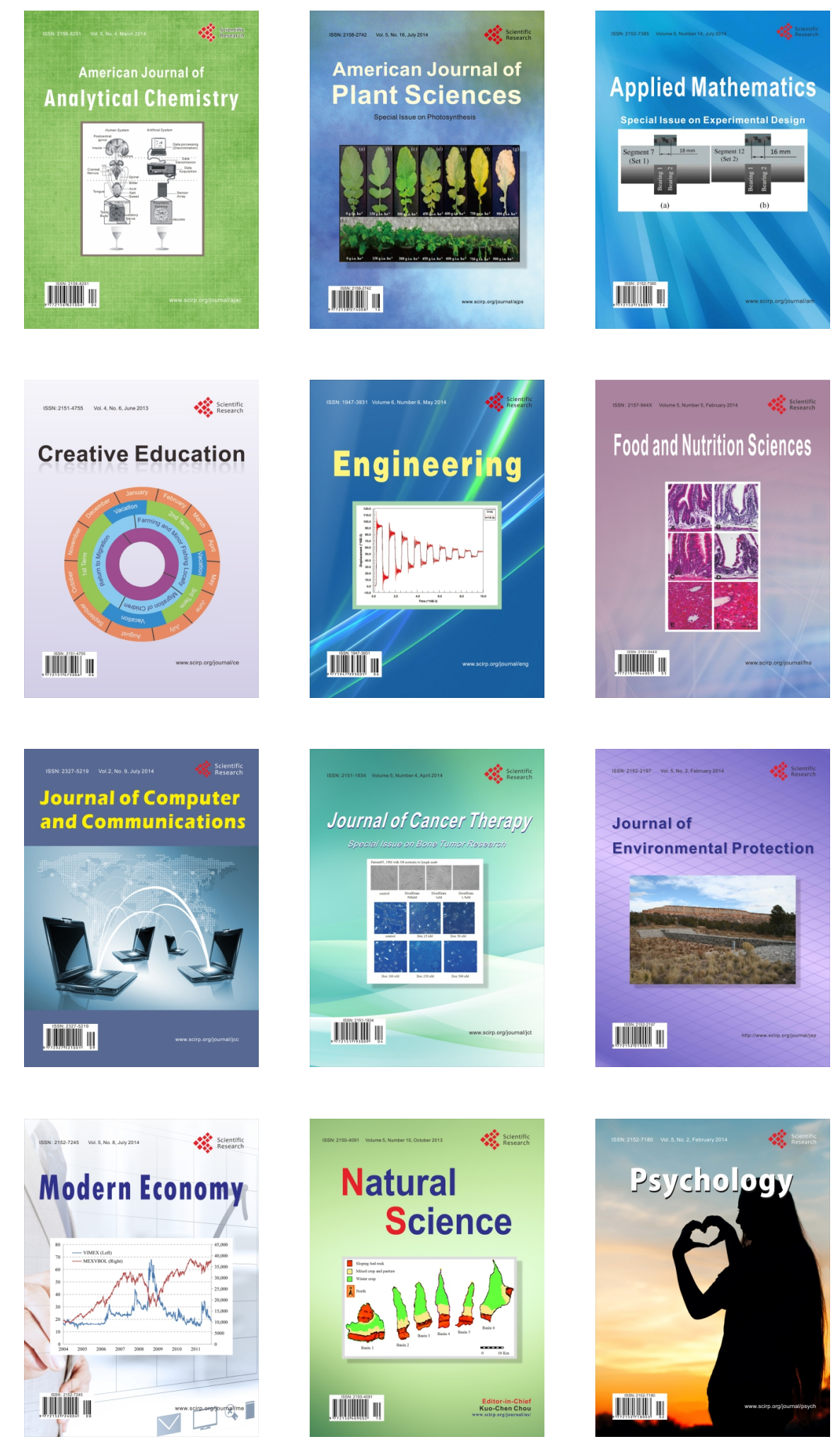